\title{
STUDI GEOKIMIA BATUAN INDUK DAN PEMODELAN CEKUNGAN BLOK BERAU BARAT CEKUNGAN BERAU PAPUA BARAT
}

\author{
HENDRO SITUMORANG, ASEP H. KESUMAJANA, EDDY A. SUBROTO
}

\author{
Program Studi Teknik Geologi, Fakultas Ilmu dan Teknologi Kebumian, Institut Teknologi Bandung (ITB), Jl \\ Ganesha No.10, Bandung, Jawa Barat, Indonesia, 40132, Email: hendro.situmorang @ yahoo.com
}

\begin{abstract}
Sari - Eksplorasi pada Cekungan Berau telah dilakukan sejak 30 tahun yang lalu. Telah dilakukan pengeboran dengan target Formasi Kais, Formasi Kembelangan Bawah dan Formasi Tipuma. Beberapa sumur kering dan pada sumur Gunung-1 ditemukan penampakan minyak (oil show). Umumnya studi yang dilakukan pada cekungan ini adalah studi reservoir dan perangkap, sedangan geokimia dan pembentukan hidrokarbon jarang dilakukan. Analisis batuan induk telah dilakukan pada setiap formasi sumur Gunung-1. Formasi yang berpotensi menjadi batuan induk pada cekungan ini adalah Formasi Kembelangan Bawah pada umur Jura dan Formasi Tipuma pada umur Trias. Hasil dari korelasi biomarker sampel minyak berkorelasi positif dan menandakan minyak tersebut satu famili. Korelasi biomarker juga dilakukan pada sampel minyak dan Formasi Kembelangan Bawah. Keduanya berkorelasi positif dan material organiknya tersusun atas campuran yang diendapkan di lingkungan estuarin.
\end{abstract}

Berdasarkan hasil pemodelan cekungan, pada saat ini Formasi Kembelangan Bawah pada sumur Gunung-1 berada pada kematangan matang akhir. Formasi ini memasuki tahap matang awal pada Kapur Akhir, matang puncak pada Paleosen Akhir dan matang akhir pada Eosen Tengah.

Cekungan Berau telah memiliki sistem petroleum yang lengkap. Selain kelengkapan elemen sistem petroleum, waktu pembentukan element tersebut merupakan hal yang sangat penting. Perangkap (Antiklin Misool-Onin-Kumawa) terbentuk pada Miosen Akhir-Pliosen. Minyak tidak terakumulasi dengan baik pada perangkap tersebut karena minyak telah terbentuk pada Kapur akhir. Berdasarkan kematangannya Formasi Kembelangan Bawah masih berpotensi menghasilkan minyak namun Transformation Ratio sudah mencapai 100\% pada Oligosen Awal sehingga batuan induk berhenti menghasilkan

Kata kunci: batuan induk, Cekungan Berau, kematangan, lingkungan pengendapan, pemodelan cekungan

\begin{abstract}
Eksploration around Berau Basin had been made since the last 30 years with the drilling objective to test Kais Formation, Lower Kembelangan Formation dan Tipuma Formation. Gunung-1 well is finded oil show and the other well is dry hole. Study in this area generally only at reservoir and trap study. Study of geochemistry and source rock maturity is rarely. Source rock analysis had been done at every formation Gunung-1 well. Lower Kembelangan Formation and Tipuma Formation is the best rock sample for source rock in this basin. The Biomarker Lower Kembelangan Formation and oil sample had been analysis. Oil sample is showing posstive correlation and one family oil. The biomarker analysis between Lower Kembelangan and oil sample is showing positive correlation. The both composed from mixing organic material which deposition in estuarine environment.
\end{abstract}

Base on result of 1 dimension basin modeling, Lower Kembelangan Formation showing late mature maturity. Maturity of this formation is early mature at Late Cretaceous, peak mature at late Paleocene and late mature at Middle Eocene.

Berau Basin have complete petroleum system element, however, time of forming of element is important. Trap (MOKR) was formed at Late Mocene-Pliocene. Time of trap forming caused not form hydrocarbon accumulation in this trap, because at this time source rock has been stopped generate hydrocarbon. Transformation ratio was acchive $100 \%$ at Early Oligosen.

Keyword: source rock, Berau Basin, maturity, depositional environtment, basin modeling. 


\section{PENDAHULUAN}

Cekungan Berau merupakan salah satu cekungan yang ada di Kawasan Indonesia Bagian Timur tepatnya di daerah Kepala Burung. Cekungan ini merupakan salah satu cekungan yang berbatasan langsung dengan Cekungan Salawati di sebelah utara dan Cekungan Bintuni di sebelah timur yang telah terbukti sebagai cekungan yang menghasilkan hidrokarbon. Cekungan Berau memiliki stratigrafi yang sama dengan kedua cekungan tersebut, sehingga cekungan ini juga sangat berpotensi menghasilkan hidrokarbon. Namun setelah dilakukan pemboran beberapa sumur kering (dry hole) dan satu sumur didapatkan penampakan minyak (oil show). Penelitian ini mencoba untuk menganalisis batuan induk penghasil minyak pada cekungan ini dengan mengkorelasikan minyak terhadap batuan induk yang berpotensi. Berdasarkan data geologi, geokomia dan geofisika dilakukan juga pemodelan cekungan terhadap sistem petroleum yang terbentuk untuk mengetahui sebaran kematangan pada batuan induk.

\section{Geologi Regional}

Daerah penelitian berada di Cekungan Berau, Papua Barat tepatnya di bagian Kepala Burung yang merupakan bagian dari Kerak Benua Autraslia. Pada saat ini Cekungan Berau dipengaruhi oleh konvergensi antara Lempeng pasifik terhadap Lempeng Australia di utara dan Konvergensi Busur Banda di baratlaut.cekunga Berau dibatasi Tinggian Ayamaru dibagian utara, punggungan Sekak dibagian timur. (Gambar 1).

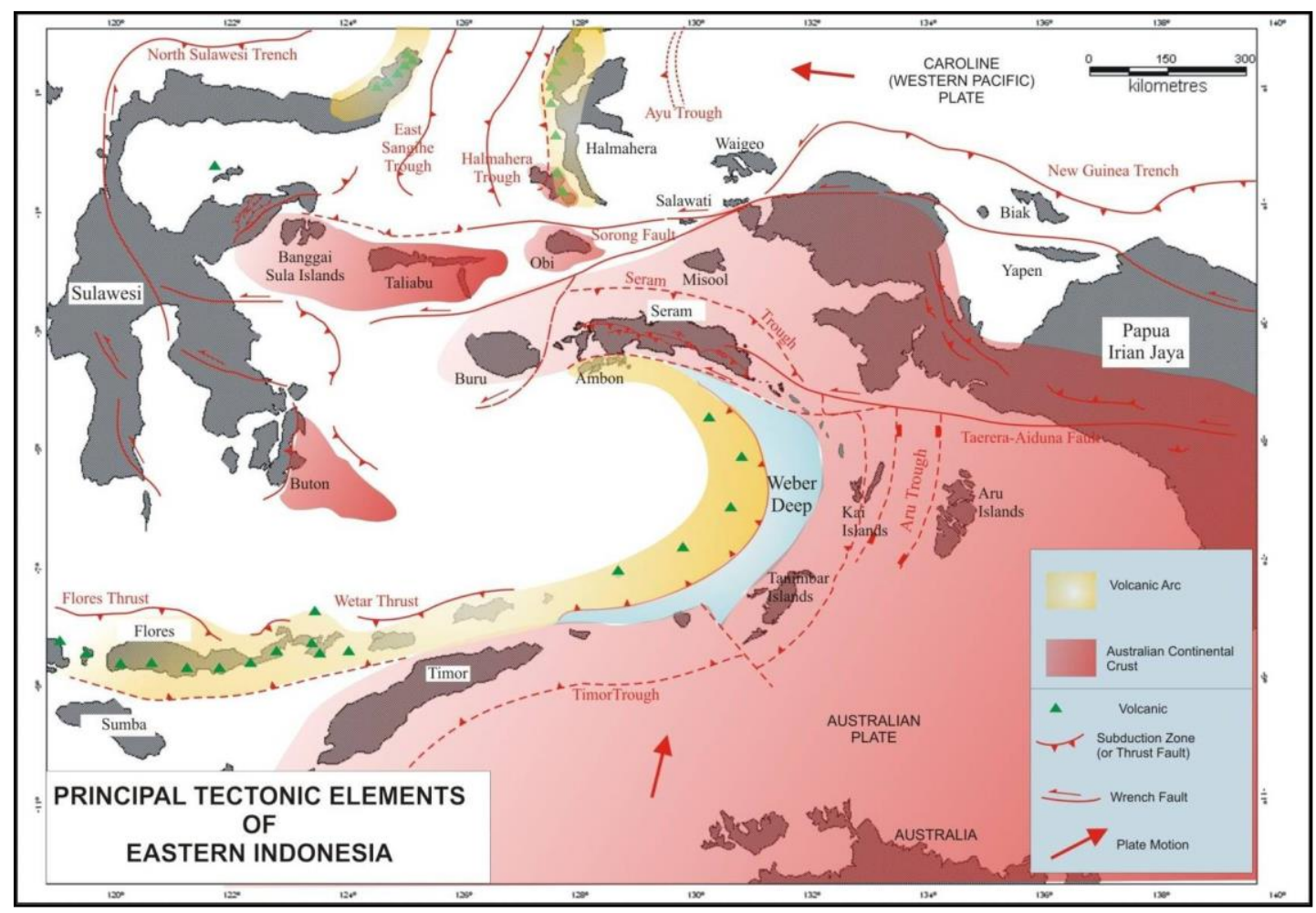

Gambar 1. Kondisi tektonik Papua Barat dan lokasi penelitian (Nillandaroe dan Barraclough, 2003 dalam Yunus, 2010).

\section{Stratigrafi}

Cekungan Berau terdiri dari batuan-batuan yang berumur Pra-Tersier sampai Tersier. Batuan dasar ini tersingkap di Tinggian Kemum. Formasi Kemum berumur SilurDevon terdiri dari batu sabak, filit, batupasir dan kuarsit yang mengalami metamorfosa derajat rendah. Di atas Formasi Kemum diendapkan secara tidak selaras Kelompok Aifam, yang terdiri dari Formasi Aimau, Formasi Aifat, dan Formasi Ainim. 


\section{- Pra-Tersier}

Formasi Tipuma diendapkan di atas Formasi Ainim pada umur Trias-Jura. Formasi ini diendapkan secara tidak selaras dengan batuannya meliputi perlapisan antara batupasir dan serpih yang diendapkan pada lingkungan aluvial-kontinental dengan regresi laut.

Kelompok Kembelangan diendapkan di atas Formasi Tipuma. Kelompok ini terdiri dari Formasi Kembelangan Bawah dan Formasi Jass. Formasi Kembelangan Bawah diendapkan pada umur Jura-Kapur, berupa endapan batupasir laut dangkal.

\section{- Tersier}

Di atas Formasi ini diendapkan Kelompok Batugamping New Guinea yang terdiri dari Formasi Waripi, Formasi Faumai, Formasi Sirga, dan Formasi Kais. Formasi Faumai diendapkan pada umur Eosen dan batuannya berupa batugamping. Formasi Sirga memiliki umur Oligosen Akhir-Miosen Awal, formasi ini diendapkan di atas Formasi Faumai. Formasi Sirga terdiri dari endapkan batugamping. Formasi Kais terendapkan pada umur Miosen Awal-Miosen Tengah dengan litologinya berupa batugamping dengan banyak dijumpai koral. Formasi Klasafet diendapkan di atas Formasi Kais yaitu diendapkan pada umur Misoen Akhir. Formasi Steenkool mulai diendapkan pada umur Pliosen, terdiri dari perlapisan antara serpih dan batupasir.

\section{DATA DAN METODOLOGI}

\subsection{Data}

Data yang digunakan dalam penelitian ini adalah data sumur dan data seismik. Data sumur yang digunakan adalah sumur TBJ-1X, North onin-1X dan Gunung-1. Analisis data geokimia menggunakan data sumur Gunung-1

\subsection{Metodologi}

Secara umum metode yang digunakan dalam penelitian adalah metode interpretasi data log sumur dan data seismik yang kemudian diintergrasikan dengan data geokimia batuan induk untuk membuat pemodelan cekungan.

\subsubsection{Analisis Geologi}

Analisis ini meliputi analisis biostratigrafi, analisis geokimia dan analisis petrofisika. Analisis biostratigrafi dilakukan untuk mendapatkan markah yang digunakan untuk Penentuan horizon dan dipetakan pada penampang seismik. Analisis geokimia dilakukan pada Sumur Gunung-1. Pada analisis geokimia juga dilakukan koreksi terhadap Ro menggunakan persamaan garis dari Syaifudin (1999). Analisis pertofisika dilakukan pada mud log untuk mengetahui komposisi litologi tiap lapisan dan menghitung tebal erosi menggunakan log sonik yang dikonversi menjadi nilai porositas. Konversi dilakukan dengan persamaan Raiga- Clemencau (Isller, 1992 dalam Kesumajana, 1997)

$$
\varnothing=1-\left(\frac{t_{m a}}{t_{\log }}\right)^{1 / x}
$$

\subsubsection{Analisis Geofisika}

Analisis geofisika meliputi pemetaan horizon bawah permukaan, pengikatan data sismik, serta pembauatan peta struktur bawah permukaan. Hasil analisis geofisika ini akan digunakan untuk data masukan pemodelan cekungan 2D dan 3D

\subsubsection{Pemodelan 1D dan 3D}

Pemodelan cekungan 1D merupakan integrasi dari data umur batuan, paleobatimetri, analisis erosi dan analisis geokimia yang di validasi dengan nilai Ro dan nilai BHT. Intergrasi pemodelan cekungan 1D terhadapa peta struktur bawah permukaan akan menghasilkan pemodelan cekungan 3D.

\section{Hasil Penelitian}

\subsection{Analisis Batuan Induk}

Berdasarkan nilai TOC Formasi Kembelangan bawah, Tipuma dan Kelompok Aifam yang paling baik sebagai batuan induk (Gambar 2). Nilai HI dari setiap formasi menunjukkan umumnya semua formasi didominasi oleh kerogen tipe III sedangkan hanya Formasi Kembelangan bawah yang memiliki sampel yang termasuk kerogen Tipe II yang cukup banyak (Gambar 3). Dilakukan plot silang 
data Ro terhadap kedalaman (Gambar 4). Nilai Ro sampel Formasi Kembelangan Bawah pada cekungan ini mengalami supresi. Koreksi nilai Ro pada sampel Formasi Kembelangan Bawah dilakukan dengan persemaan garis yang Syaifudin (1999). (Tabel 1). Berdasarkan klasifikasi Peters dan Cassa (1994), formasi yang berpotensi menjadi batuan induk pada cekungan ini adalah Formasi Kembelangan Bawah dan Formasi Tipuma (Tabel 2). Untuk selanjutnya dilakukan analisis biomarker pada Formasi Kembelangan Bawah untuk dikorelasikan biomarkernya dengan sampel minyak yang didapatkan pada tes sumur pada kedalaman 11.740 dan 11.984 kaki. Berdasarkan hasil analisis biomarker isopreonoid dan sterana, Formasi Kembelangan Bawah terendapkan di lingkungan pengendapan estuarin tersusun atas material darat dan alga laut (Gambar 5). Berdasarkan analisis kualitatif dan kuantitatif biomarker sterana serta terpana sampel ekstrak Formasi Kembelangan Bawah berkorelasi positif dengan sampel minyak dan menandakan bahwa minyak dihasilkan oleh Formasi Kembelangan Bawah. (Gambar 6).

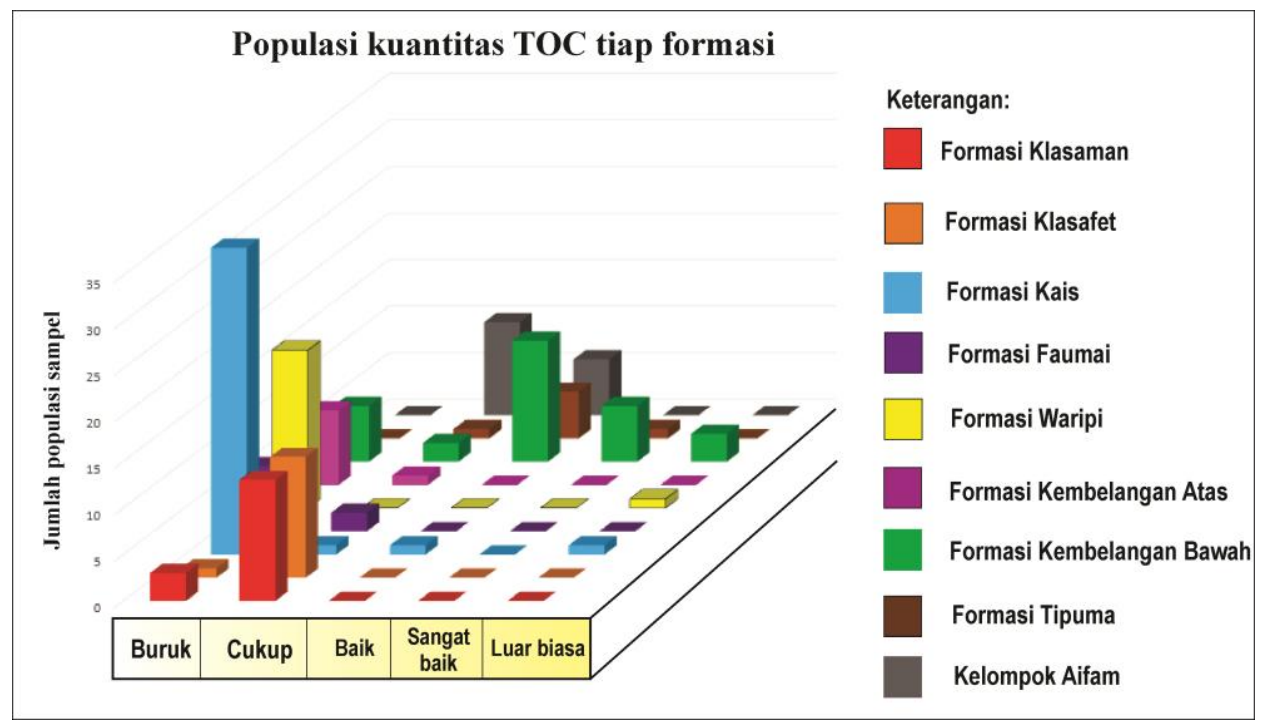

Gambar 2. Populasi kuantitas TOC pada semua formasi Sumur Gunung-1.

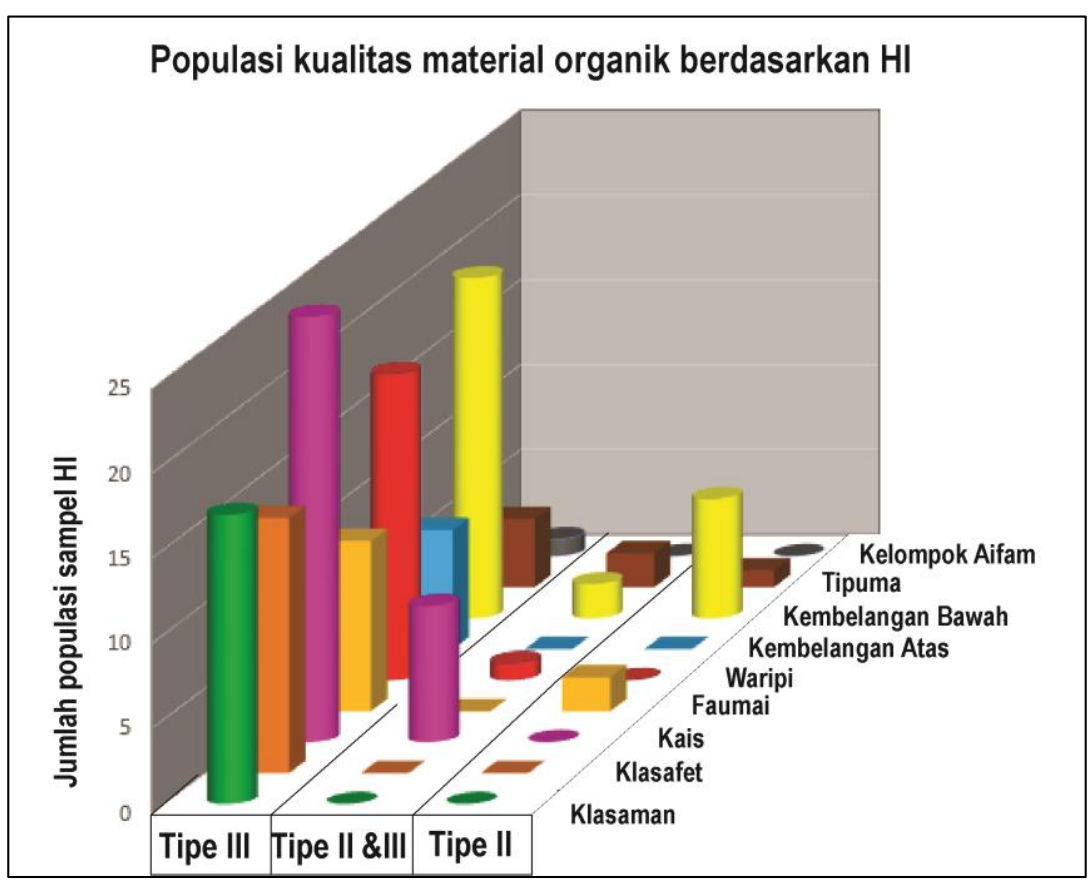

Gambar 3. Populasi nilai HI tiap formasi pada semua sampel yang dianalisis. 


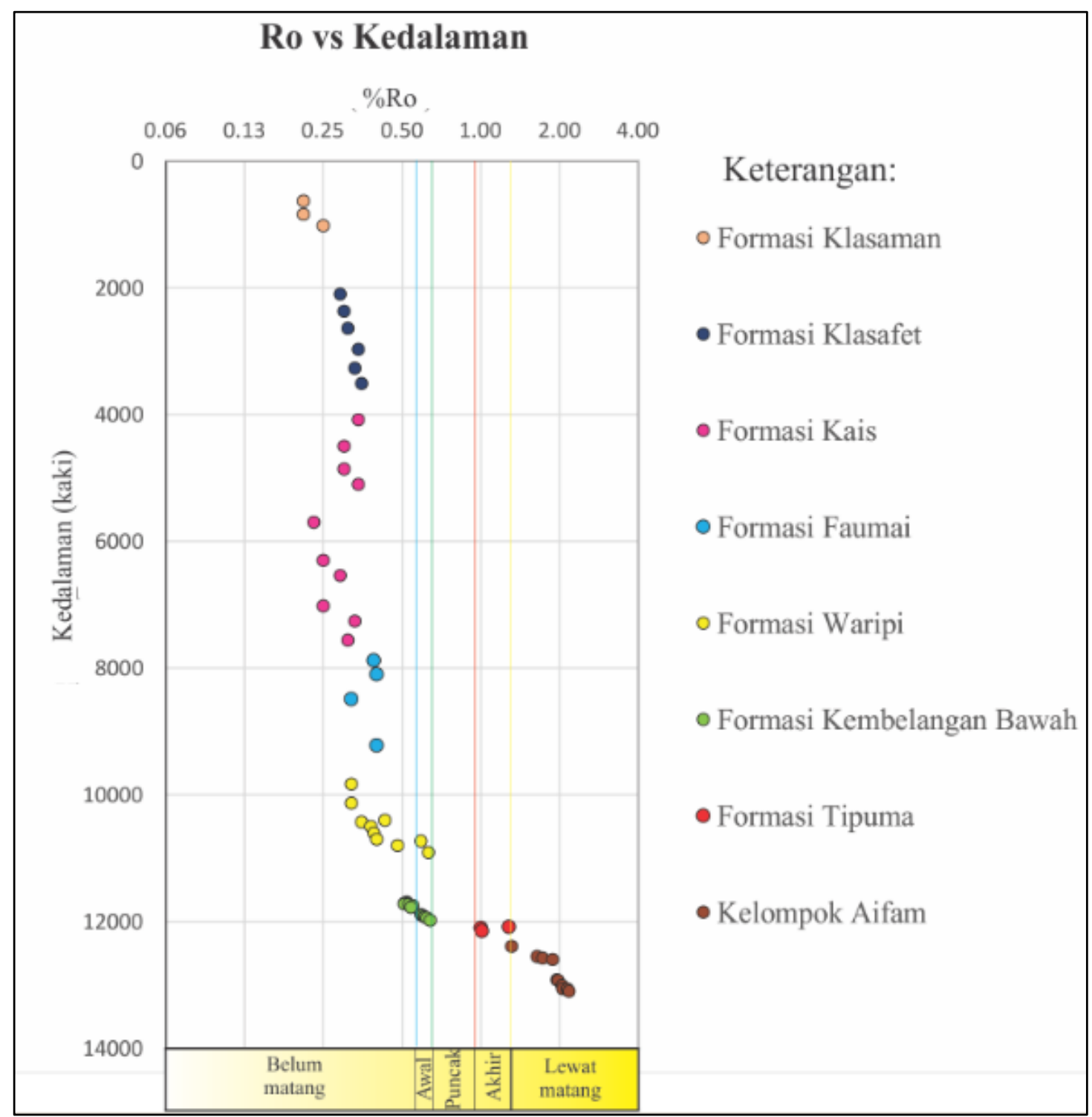

Gambar 4. Plot silang nilai Ro terhadap kedalaman dari semua formasi sumur Gunung-1.

Tabel 1. Hasil koreksi Ro.

\begin{tabular}{|c|c|c|c|c|c|c|}
\hline $\begin{array}{c}\text { Kedalaman } \\
\text { (kaki) }\end{array}$ & Formasi & $\begin{array}{c}\text { HI } \\
(\mathrm{mg} / \mathrm{g})\end{array}$ & $\begin{array}{c}\text { Tmaks } \\
\left({ }^{\circ} \mathrm{C}\right)\end{array}$ & $\begin{array}{c}\text { Ro terukur } \\
(\mathrm{wt} \%)\end{array}$ & $\begin{array}{c}\text { Ro koreksi } \\
\text { Syaifudin (1999) }\end{array}$ & Terkoreksi \\
\hline 11.712 & Kembelangan Bawah & 483 & 446 & 0,51 & 0,93 & 0,42 \\
\hline 11.725 & Kembelangan Bawah & 464 & 441 & 0,53 & 0,98 & 0,45 \\
\hline 11.774 & Kembelangan Bawah & 185 & 447 & 0,54 & 0,75 & 0,15 \\
\hline 11.894 & Kembelangan Bawah & 193 & 445 & 0,59 & 0,80 & 0,19 \\
\hline 11.926 & Kembelangan Bawah & 155 & 450 & 0,61 & 0,81 & 0,20 \\
\hline 11.940 & Kembelangan Bawah & 158 & 448 & 0,62 & 0,83 & 0,21 \\
\hline 11.980 & Kembelangan Bawah & 302 & 450 & 0,64 & 1,23 & 0,59 \\
\hline
\end{tabular}


Tabel 2. Rangkuman hasil evaluasi batuan induk seluruh formasi pada Sumur Gunung-1.

\begin{tabular}{|c|c|c|c|c|c|}
\hline \multirow{2}{*}{ Formasi } & \multicolumn{2}{|c|}{ Kuantitas } & \multirow{2}{*}{$\begin{array}{c}\text { Kualitas } \\
\text { HI (mg/g) } \\
\text { (tipe Kerogen) }\end{array}$} & \multicolumn{2}{|c|}{ Kematangan } \\
\hline & $\begin{array}{c}\text { TOC } \\
(w t \%)\end{array}$ & $\begin{array}{c}\text { PY( S1+S2) } \\
\text { mg/gm }\end{array}$ & & $\%$ Ro & $\begin{array}{c}\text { Tmaks } \\
\left({ }^{\circ} \mathrm{C}\right)\end{array}$ \\
\hline Klasaman & $\begin{array}{c}\text { Buruk-cukup } \\
(0,11-0,89) \\
\end{array}$ & $\begin{array}{c}\text { Buruk } \\
(0,15-0,78) \\
\end{array}$ & $\begin{array}{c}\text { III } \\
(30-72) \\
\end{array}$ & $\begin{array}{l}\text { Belum matang } \\
(0,21-0,25) \\
\end{array}$ & $\begin{array}{c}\text { Belum-awal matang } \\
(427-438) \\
\end{array}$ \\
\hline Klasafet & $\begin{array}{c}\text { Buruk-cukup } \\
(0,45-0,73) \\
\end{array}$ & $\begin{array}{c}\text { Buruk } \\
(0,17-0,56) \\
\end{array}$ & $\begin{array}{c}\text { III } \\
(33-72) \\
\end{array}$ & $\begin{array}{l}\text { Belum matang } \\
(0,29-0,35) \\
\end{array}$ & $\begin{array}{c}\text { Belum-awal matang } \\
(413-437) \\
\end{array}$ \\
\hline Kais & $\begin{array}{c}\text { Buruk-luar biasa } \\
(0,13-10,6)\end{array}$ & $\begin{array}{c}\text { Buruk-luar biasa } \\
(0,09-26,17) \\
\end{array}$ & $\begin{array}{l}\text { II dan III } \\
(38-294) \\
\end{array}$ & $\begin{array}{l}\text { Belum matang } \\
(0,23-0,34)\end{array}$ & $\begin{array}{c}\text { Belum-awal matang } \\
(427-437) \\
\end{array}$ \\
\hline Faumai & $\begin{array}{l}\text { Buruk-cukup } \\
(0,15-0,87) \\
\end{array}$ & $\begin{array}{c}\text { Buruk } \\
(0,1-2,04) \\
\end{array}$ & $\begin{array}{l}\text { II dan III } \\
(47-315) \\
\end{array}$ & $\begin{array}{l}\text { Belum matang } \\
\qquad(0,32-0,40)\end{array}$ & $\begin{array}{l}\text { Belum matang } \\
(429-433) \\
\end{array}$ \\
\hline Waripi & $\begin{array}{c}\text { Buruk-luar biasa } \\
(0,13-6,41) \\
\end{array}$ & $\begin{array}{c}\text { Buruk } \\
(0,06-1,55) \\
\end{array}$ & $\begin{array}{l}\text { II dan III } \\
(18-120) \\
\end{array}$ & $\begin{array}{l}\text { Belum matang } \\
(0,32-0,48) \\
\end{array}$ & $\begin{array}{c}\text { Belum-awal matang } \\
(428-436) \\
\end{array}$ \\
\hline Kembelangan Atas & $\begin{array}{r}\text { Buruk-cukup } \\
(0,12-0,56)\end{array}$ & $\begin{array}{c}\text { Buruk } \\
(0,03-0,29)\end{array}$ & $\begin{array}{c}\text { III } \\
(9-61)\end{array}$ & $\begin{array}{c}\text { Sampel rework } \\
\text { (tidak diinterpretasi) }\end{array}$ & $\begin{array}{c}\text { Belum-awal matang } \\
(428-437)\end{array}$ \\
\hline Kembelangan Bawah & $\begin{array}{c}\text { Buruk-luar biasa } \\
(0,1-13,88) \\
\end{array}$ & $\begin{array}{c}\text { Cukup-luar biasa } \\
(2,49-72,65) \\
\end{array}$ & $\begin{array}{l}\text { II dan III } \\
(39-483) \\
\end{array}$ & $\begin{array}{c}\text { Puncak-akhir matang } \\
\qquad(0,7-1,23)\end{array}$ & $\begin{array}{l}\text { Awal-puncak matang } \\
440-450 \\
\end{array}$ \\
\hline Tipuma & $\begin{array}{l}\text { Cukup-sangat baik } \\
(0,72-2,49)\end{array}$ & $\begin{array}{c}\text { Cukup } \\
(0,3-7,74) \\
\end{array}$ & $\begin{array}{l}\text { II dan III } \\
(31-305)\end{array}$ & $\begin{array}{c}\text { Akhir matang } \\
\qquad(1-1,28) \\
\end{array}$ & $\begin{array}{l}\text { Puncak-lewat matang } \\
\qquad 450-490 \\
\end{array}$ \\
\hline Kelompok Aifam & $\begin{array}{l}\text { Cukup-baik } \\
(0,59-1,96)\end{array}$ & $\begin{array}{c}\text { Buruk } \\
(0,05-1,26)\end{array}$ & $\begin{array}{c}\text { IV } \\
(<50)\end{array}$ & $\begin{array}{l}\text { Lewat matang } \\
\qquad(1,31-2,17)\end{array}$ & $\begin{array}{c}\text { Puncak-lewat matang } \\
\qquad(485-494)\end{array}$ \\
\hline
\end{tabular}

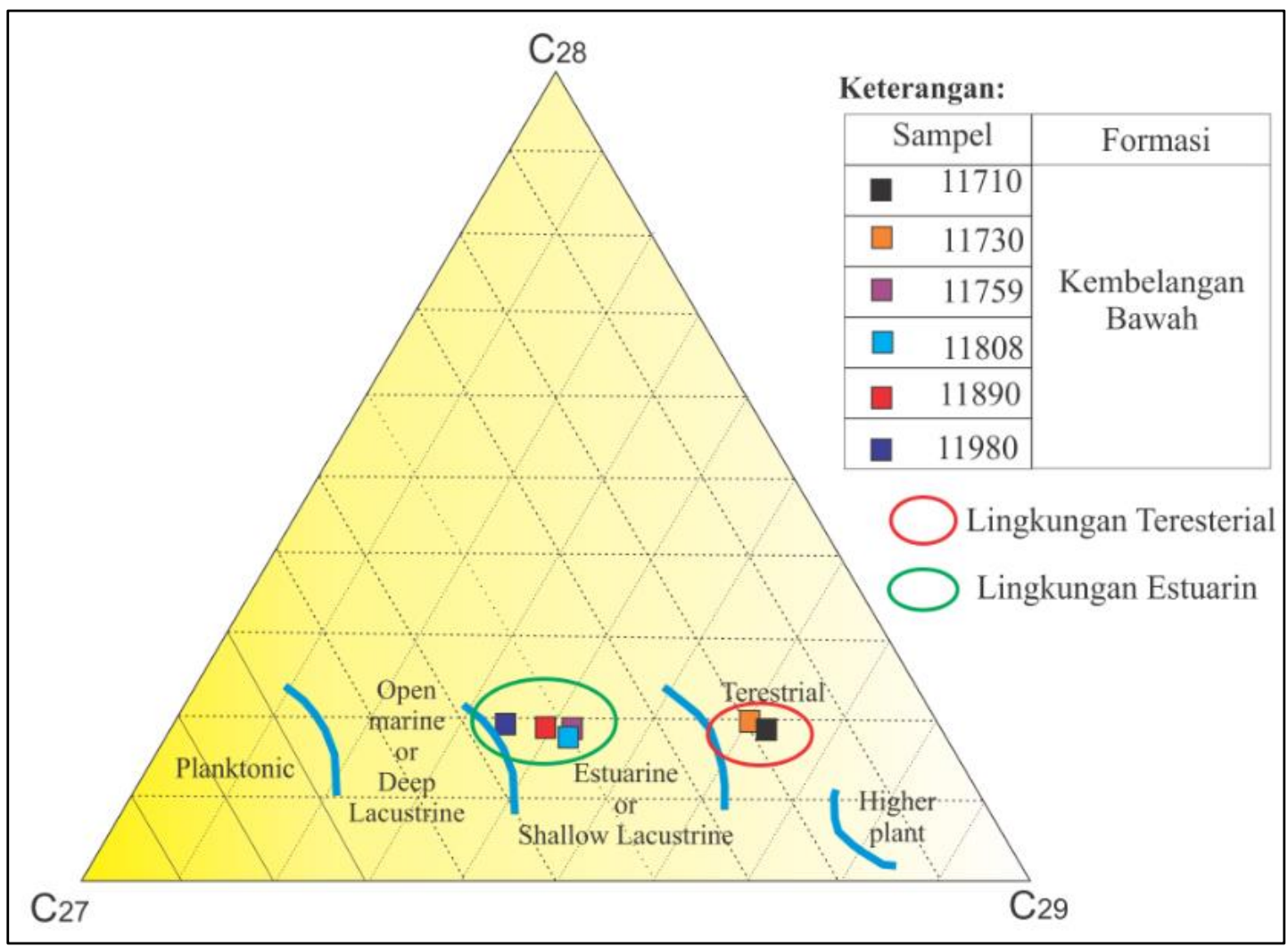

Gambar 5. Diagram segitiga sterana dari sampel Formasi Kembelangan Bawah (Huang dan Meinschein, 1979 dalam Waples dan Machihara, 1991). 


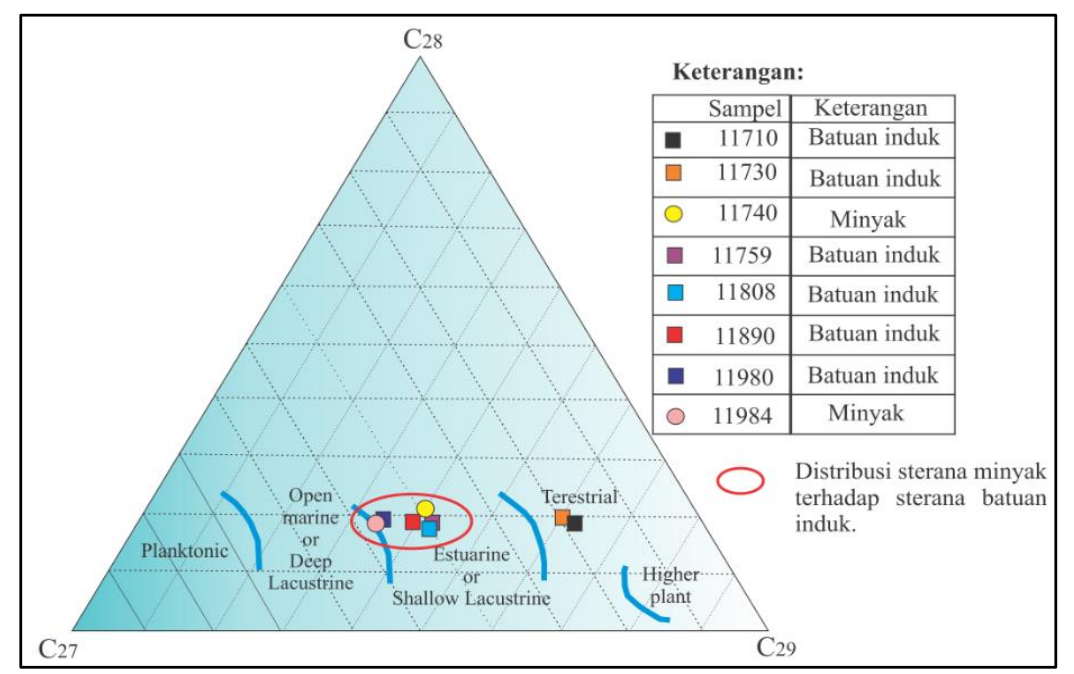

Gambar 6. Distribusi sterana sampel minyak terhadap Formasi Kembelangan Bawah (Huang dan Meinschein, 1979 dalam Waples dan Machihara, 1991).

\subsection{Biotratigrafi}

Analisis biostratigrafi dilakukan untuk menetukan umur puncak dari masing-masing formasi berdasarkan foram dan nanoplankton. Umur-umur tersebut digunakan untuk membentuk age depth curve (Gambar 7). Melalui kurva ini dapat dilakukan analisis ketidakselarasan dan juga ketebalan lapisan yg hilang.

\subsection{Data Masukan Pemodelan}

Data masukan pemodelan meliputi komposisi lapisan batuan, data geokimia, SWIT, aliran bahang (heat flow), Ro dan BHT (bottom hole temperature). Komposisi litologi pada lapisan batuan didapatkan dari mud log. Komposisi litologi yang digunakan pada penelitian ini dapat dilihat pada Tabel 3. Data geokima yang diperlukan adalah TOC dan HI. TOC yang digunakan adalah 2,64\% dan nilai HI 225 $\mathrm{mgHC} / \mathrm{g}$. Data SWIT yang digunakan berdasarkan Wygrala (1989) pada daerah Asia Tenggara dan dengan kinetic tipe II (Burnham, 1989). Data aliran bahang merupakan hasil trial and error dengan mencocokkan nilai aliran bahang dari waktu ke waktu dengan garis yang memotong nilai Ro dan BHT yang paling tepat. Jika garis telah tepat memotong maka nilai aliran bahang dapat digunakan dan model sudah tervalidasi (Gambar 8).

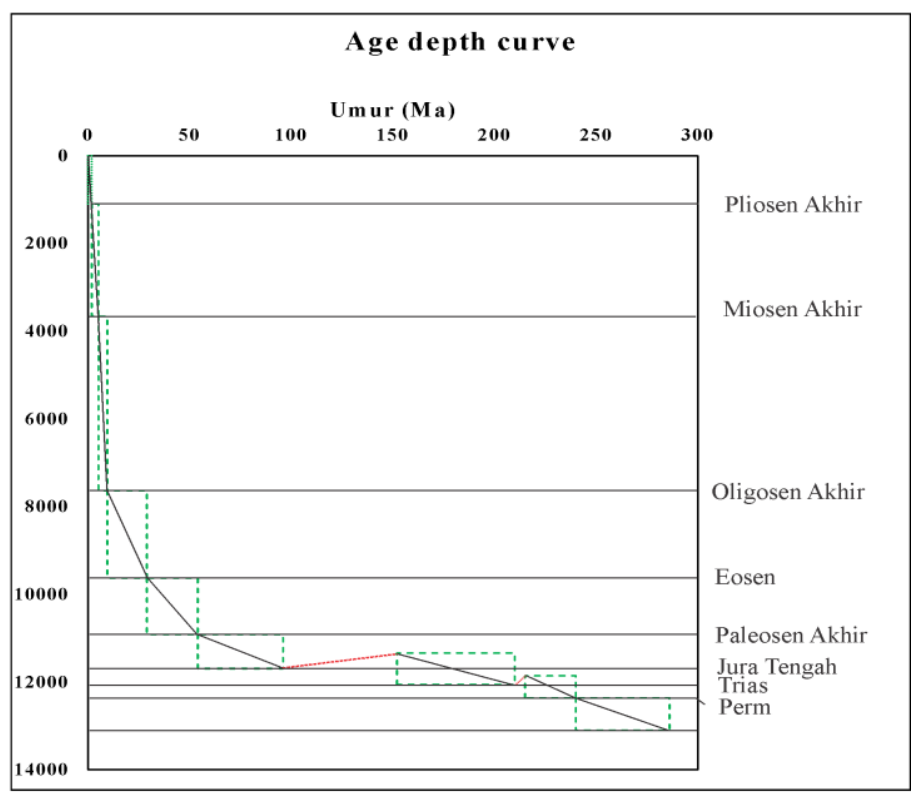

Gambar 7. Age depth curve dan erosi Sumur Gunung-1. 
Tabel 3. Komposisi litologi yang digunakan pada pemodelan cekungan 1D.

\begin{tabular}{|c|c|c|c|c|c|}
\hline Lapisan & \multicolumn{5}{|c|}{$\%$ litologi } \\
\hline Dari - ke & Batupasir & Serpih & Batugamping & Dolomit & Granit \\
\hline Resen - Pliosen Akhir & 15 & 57 & 28 & - & - \\
\hline Pliosen Akhir - Miosen Tengah & - & 89 & 11 & - & - \\
\hline Miosen Tengah - Oligosen Akhir & - & - & 96 & 4 & - \\
\hline Oligosen Akhir - Paleosen Akhir & 1.5 & 24 & 45.5 & 29 & - \\
\hline Paleosen Akhir - Jura Tengah & - & 40 & 60 & - & - \\
\hline Jura Tengah - Jura Awal & 35 & 46 & 19 & - & - \\
\hline Jura Awal - Trias Akhir & 25 & 56 & 19 & - & - \\
\hline Trias Akhir- Batuan dasar & 42 & 37 & 21 & - & - \\
\hline Batuan dasar & - & - & - & - & 100 \\
\hline
\end{tabular}

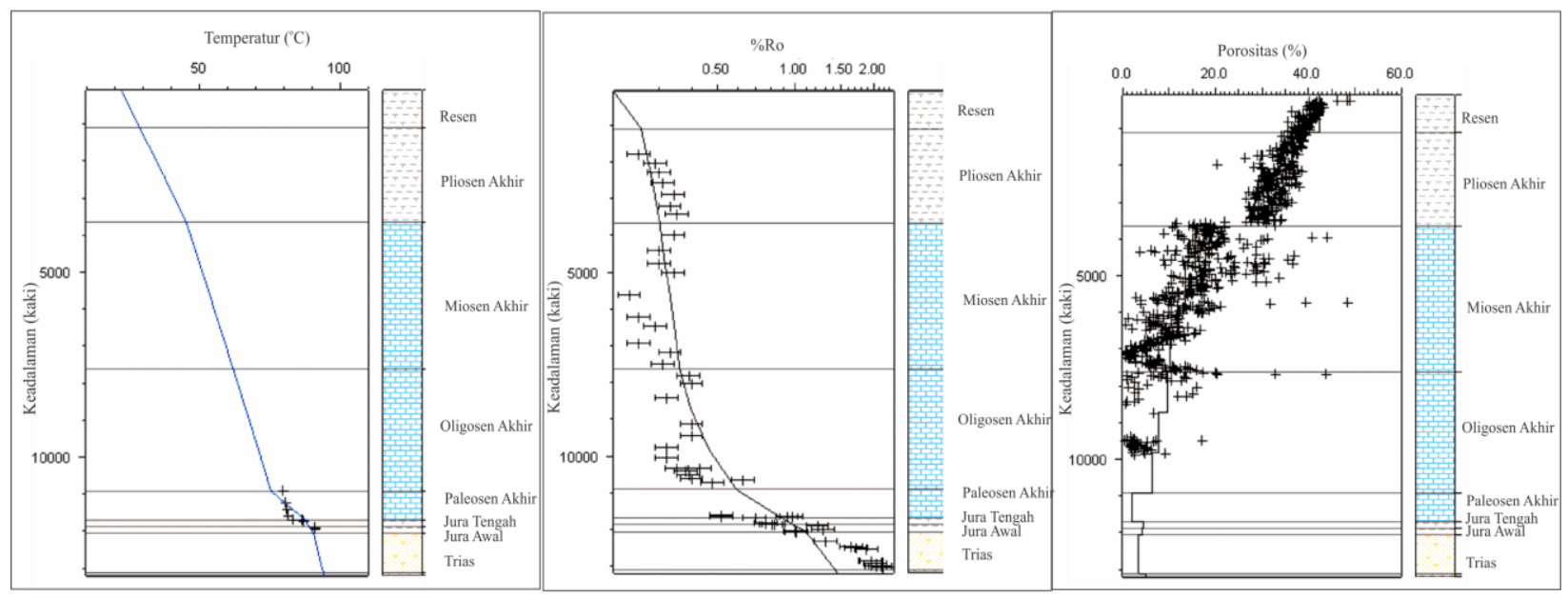

Gambar 8. Kalibrasi temperatur (kiri), kalibrasi pantulan vitrinit (tengah) dan kalibrasi porositas (kanan).

\subsection{Pemodelan Cekungan 1D}

Pemodelan Cekungan 1D dilakukan dengan data masukan pada pembahasan sebelumnya. Berdasarkan data tersebut dihasilkan Pemodelan Cekungan 1D yang menggambarkan pemendaman dan kematangan tiap lapisan (Gambar 9). Dengan mengunakan klasifikasi Peters dan Cassa (1994). Formasi Kembelangan Bawah pada 75 Ma memasuki tahap matang awal, pada umur $68 \mathrm{Ma}$ memasuki tahap matang puncak dan pada umur 45 Ma memasuki tahap matang akhir. Berdasarakan pemodelan ini juga dapat dilihat pembentukan hidrokabon yang digambarkan dengan nilai Transformation Ratio dengan menggunakan kinetik tipe II (Burham, 1989). Transformation Ratio kerogen pada Formasi Kembelangan Bawah pada 33 Ma (Oligosen Awal) telah mencapai $100 \%$.

\subsection{Pemodelan Cekungan 3D}

Pemodelan cekungan 3D merupakan hasil integrasi pemodelan cekungan 1D dengan peta struktur kedalaman. Berdasarkan pemodelan cekungan 3D persebaran kematangan pada Formasi Kebelangan Bawah (Jura Awal) dapat dilihat pada Gambar 10.

\subsection{Pemodelan Pembentukan Minyak 3D}

Ketebalan batuan induk yang digunkan hanya pada Jura Awal. Berdasarkan peta transformation ratio, $>80 \%$ luas area dari Blok Berau Barat Formasi kembelangan Bawah telah tertranformasi $100 \%$ menjadi hidrokarbon (Gambar 11). 


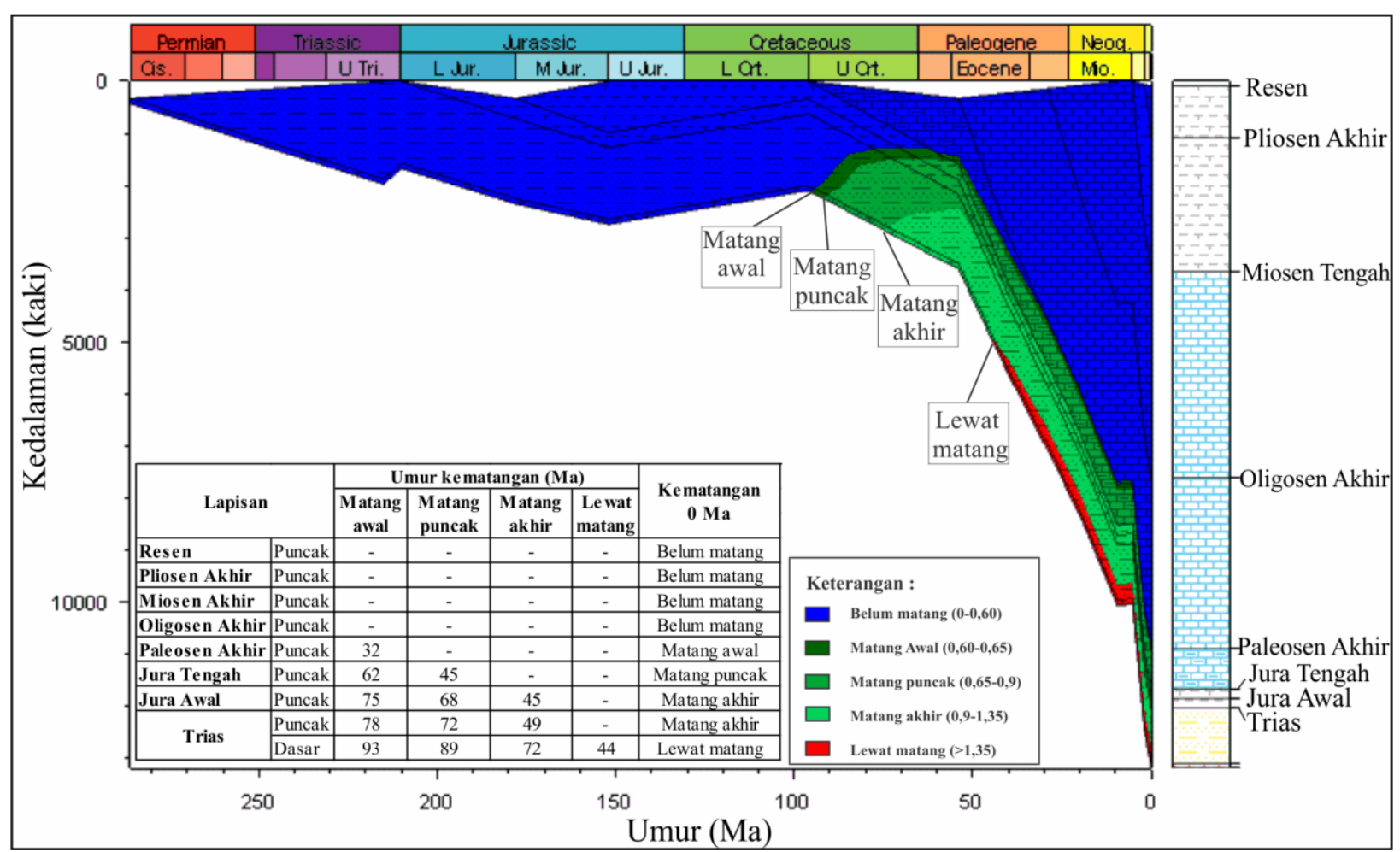

Gambar 9. Pemodelan cekungan 1D (atas) dan nilai pantulan vitrinit (\%Ro) terhadap waktu (bawah).

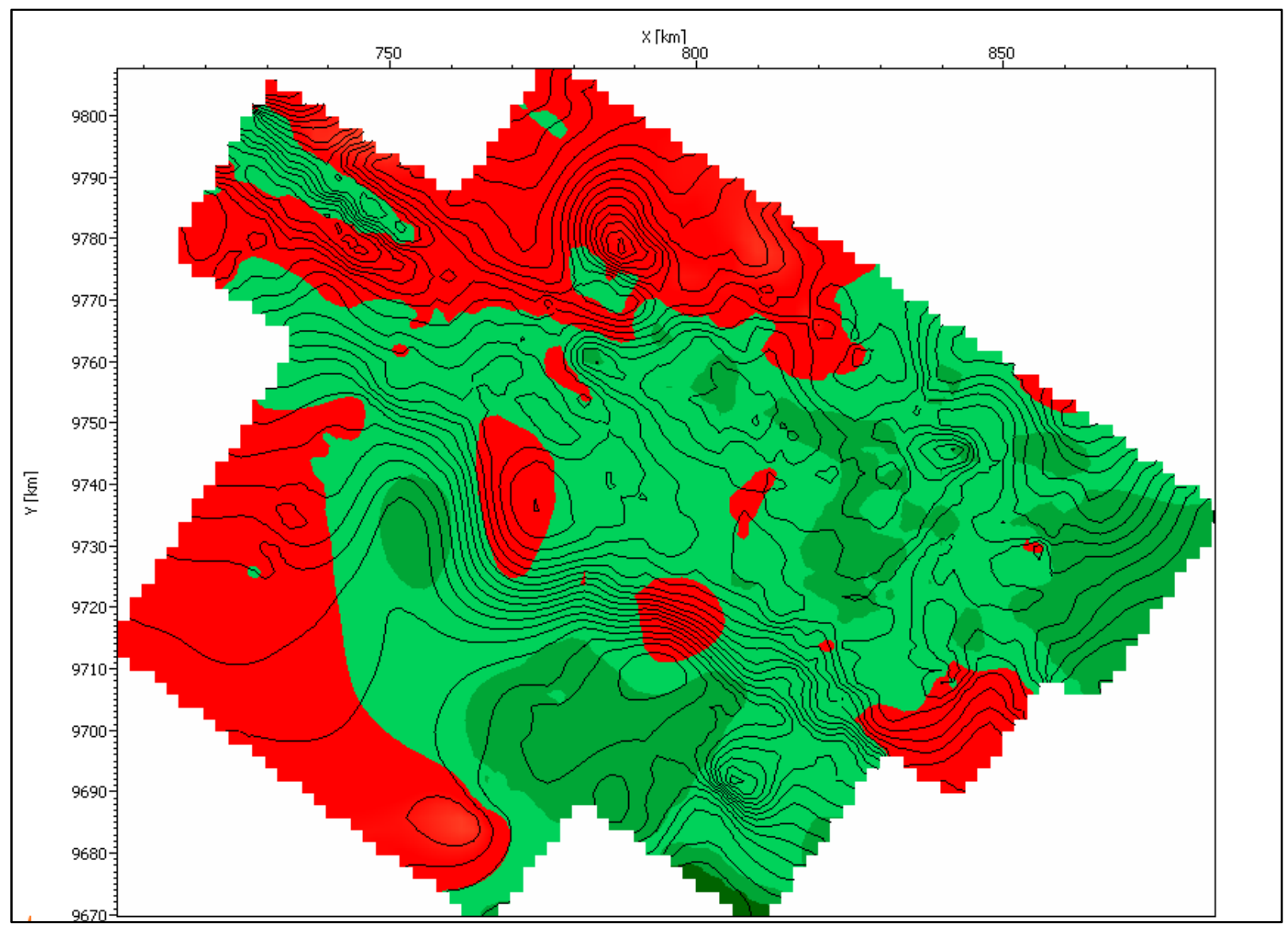

Gambar 10. Peta kematangan batuan induk saat ini pada interval puncak formasi. 


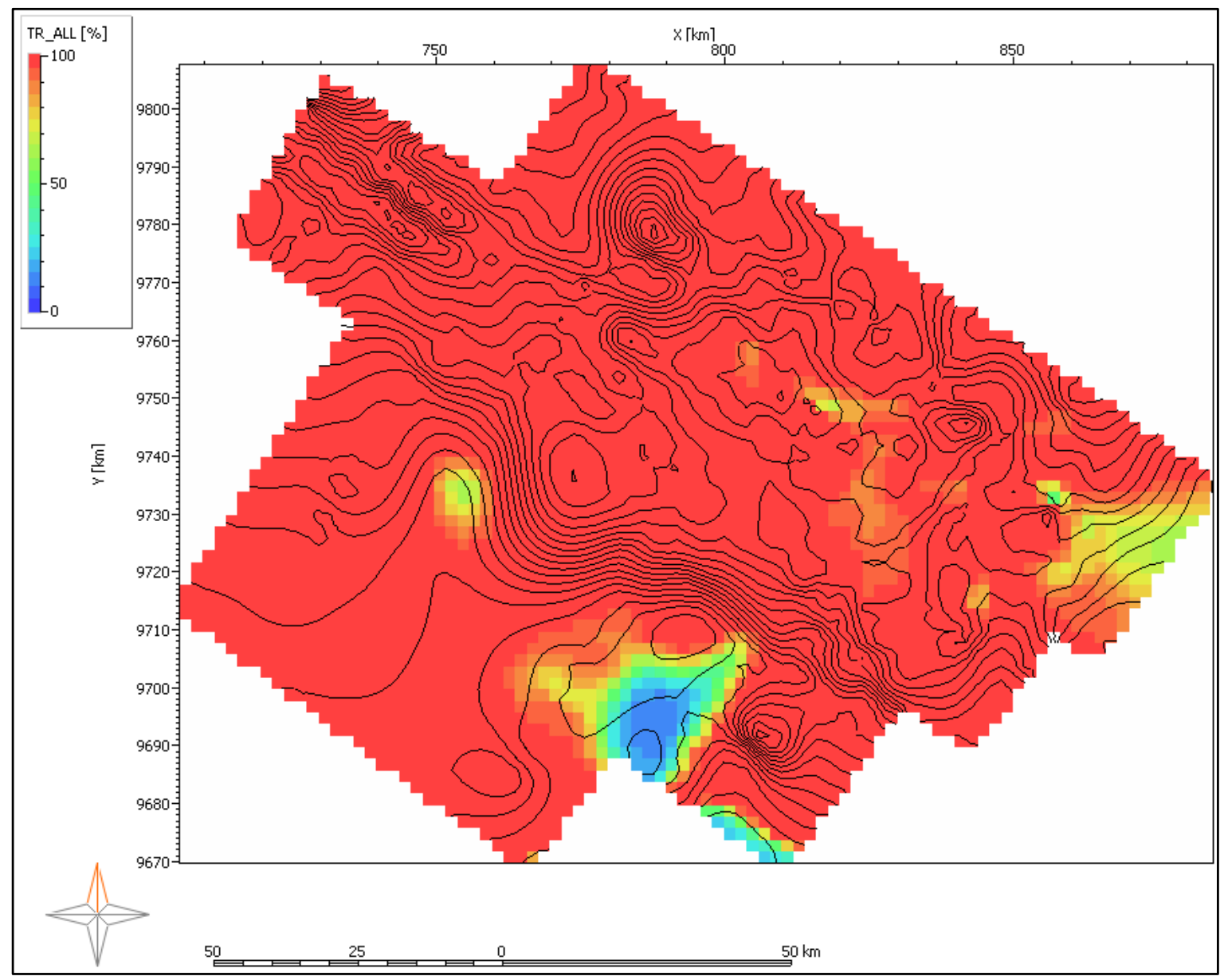

Gambar 11. Peta Transformation Ratio Formasi Kembelangan Bawah (Jura awal).

\subsection{Migrasi dan Akumulasi Minyak}

Migrasi dan akumulasi hidrokarbon pada reservoir digambarkan pada Gambar 11. Pada lapisan Jura Tengah tidak terdapat bnyak akumulasi yang terbentuk. Pada lokasi Sumur Gunung-1 juga tidak terbentuk akumulasi. Penampakan minyak (oil Show) pada interval Formasi Kembelangan Bawah yang ditemukan pada sumur tersebut diinterpretasi sebagai jalur migrasi yang dilewati minyak. Hal ini juga disebabkan karena tidak terbentuk perangkap pada lokasi Sumur-1 sehingga tidak ada akumulasi. Pada daerah tinggian Misool-OninKumawa juga tidak terbentuk akumulasi hidrokarbon. Hal ini sesuai dengan hasil tes sumur TBJ-1X yang dry hole.

\subsection{Sejarah Kematangan Batuan Induk.}

Sejarah pemendaman dapat dilihat pada Gambar 13-16. Sejarah pemendaman juga ditumpang tindih dengan sejarah kematangan sehingga keduanya dapat dijelaskan dengan baik. Pada umur 286-215 Ma terendapkan Kelompok Aifam dan Formasi Tipuma. Kelompok Aifam diendapkan sebelum lisu sedangkan Formasi Tipuma bersamaan lisu. Pada umur 215-210 Ma Formasi Tipuma tererosi. Diperkirakan erosi ini merupakan hasil dari regresi. Kemudian secara tidak selaras pada 210-152 Ma terendapkan Formasi Kembelangan Bawah yang menjadi batuan induk dan reservoir. Pemisahan Kepala Burung terhadap Lempeng Australia disertai dengan Breakup yang menyebabkan erosi pada Jura Akhir-Kapur Akhir (152-96 Ma). Selanjutnya secara tidak selaras diatas Formasi Kembelangan Bawah diendapkan Formasi Kembelangan Atas sebagai endapan passive margin pada Kapur Akhir-Paleosen Akhir (96$52 \mathrm{Ma}$ ). Formasi Kembelangan Atas terdiri 
dari serpih yang tebal dan sangat bagus untuk menjadi batuan penudung pada cekungan ini. Bersamaan dengan pengendapan Formasi kembelangan Atas, pada Umur 75 Ma, Batuan induk pada Formasi Kembelangan Bawah (Jura awal) memasuki tahap matang awal. Pada Paleosen rezim tektonik berganti menjadi rezim kompresi yan diakibatkan oleh tumbukan antara Busur Banda dan Lempeng Benua Indo-Australia (Henage, 1993). Pada konsis cekungan yang beralih dari passive margin ke foreland selanjutnya mengendapkan
Kelompok Batuan Gamping New Guinea. Formasi-formasi tersebut adalah Formasi Waripi, Formasi Faumai dan Formasi Kais (529,5 Ma). Kolisi ini menyebabkan pengangkatan dan erosi pada 9,5-5,2 Ma. Selanjutnya diendapkan Formasi Klasafet pada umur 5,2-1,8 Ma sebagai endapan bersamaan kolisi dan pada umur 1,8-0 Ma diendapkan Formasi Klasaman sebagai endapan setelah kolisi. Pada saat ini kematangan Formasi Kembelangan Bawah pada tahap matang akhir.

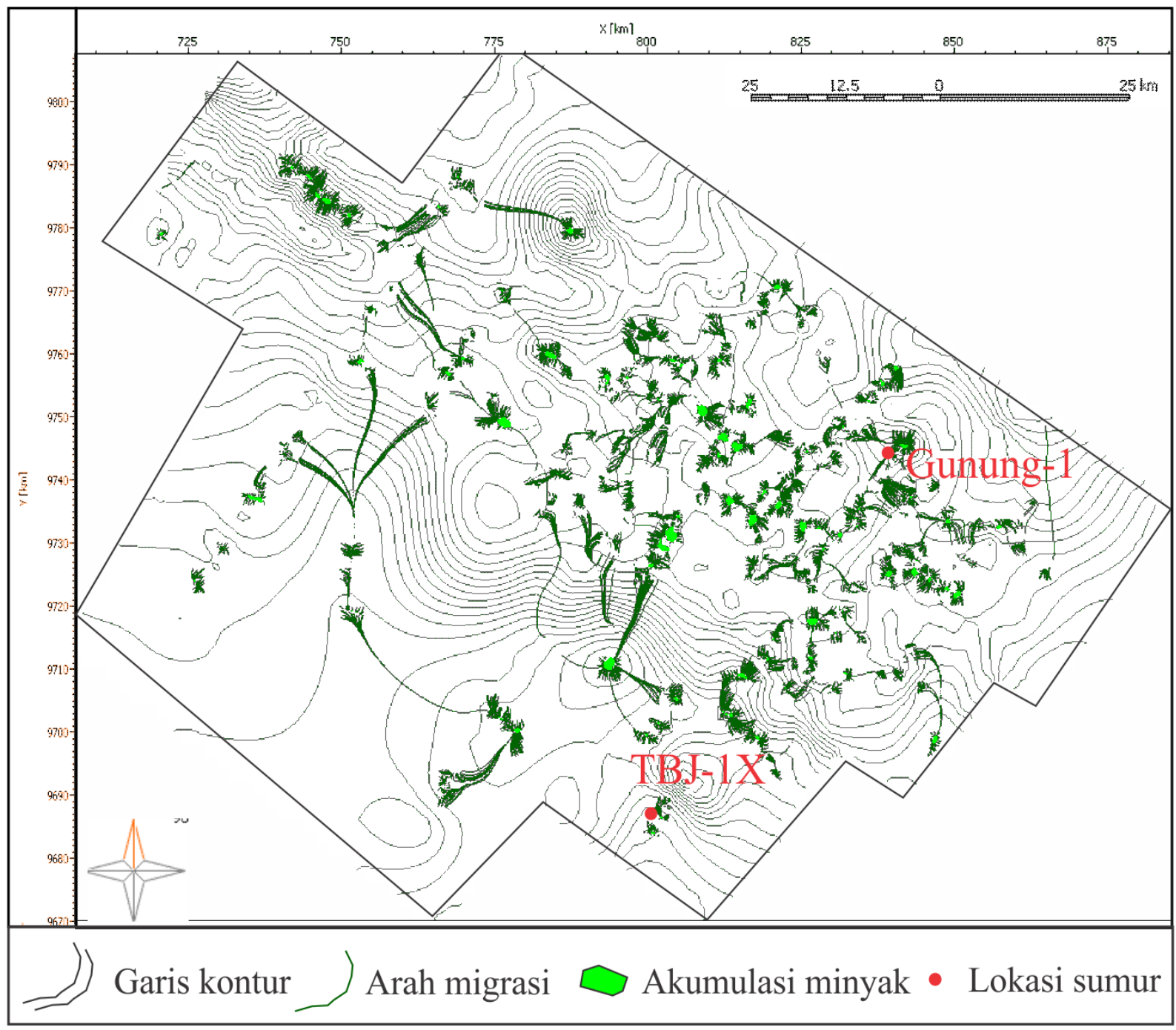

Gambar 12. Migrasi dan akumulasi minyak pada Formasi Kembelangan Bawah (Jura Tengah). 


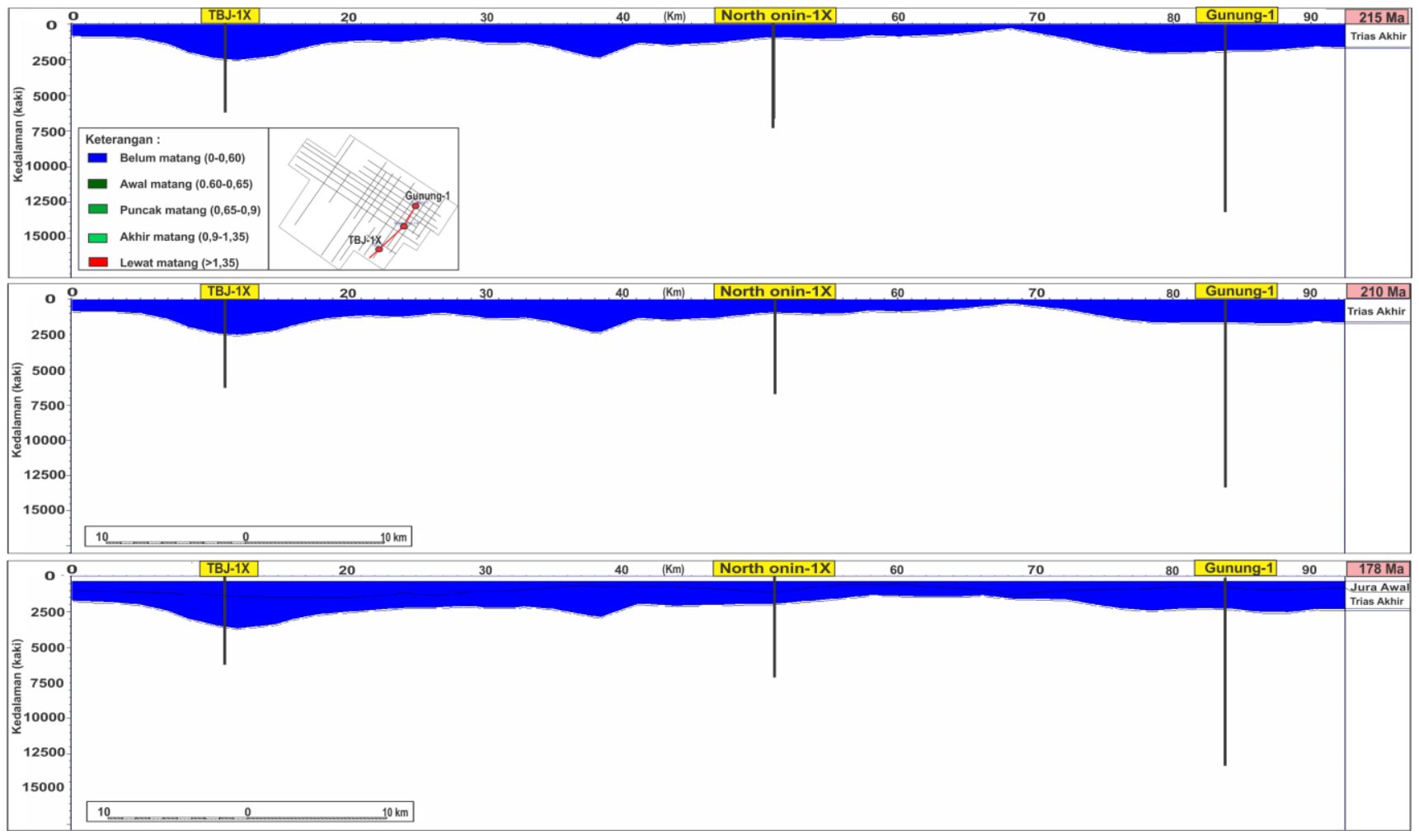

Gambar 13. Sejarah kematangan dan pemendaman 215-178 Ma Ma.

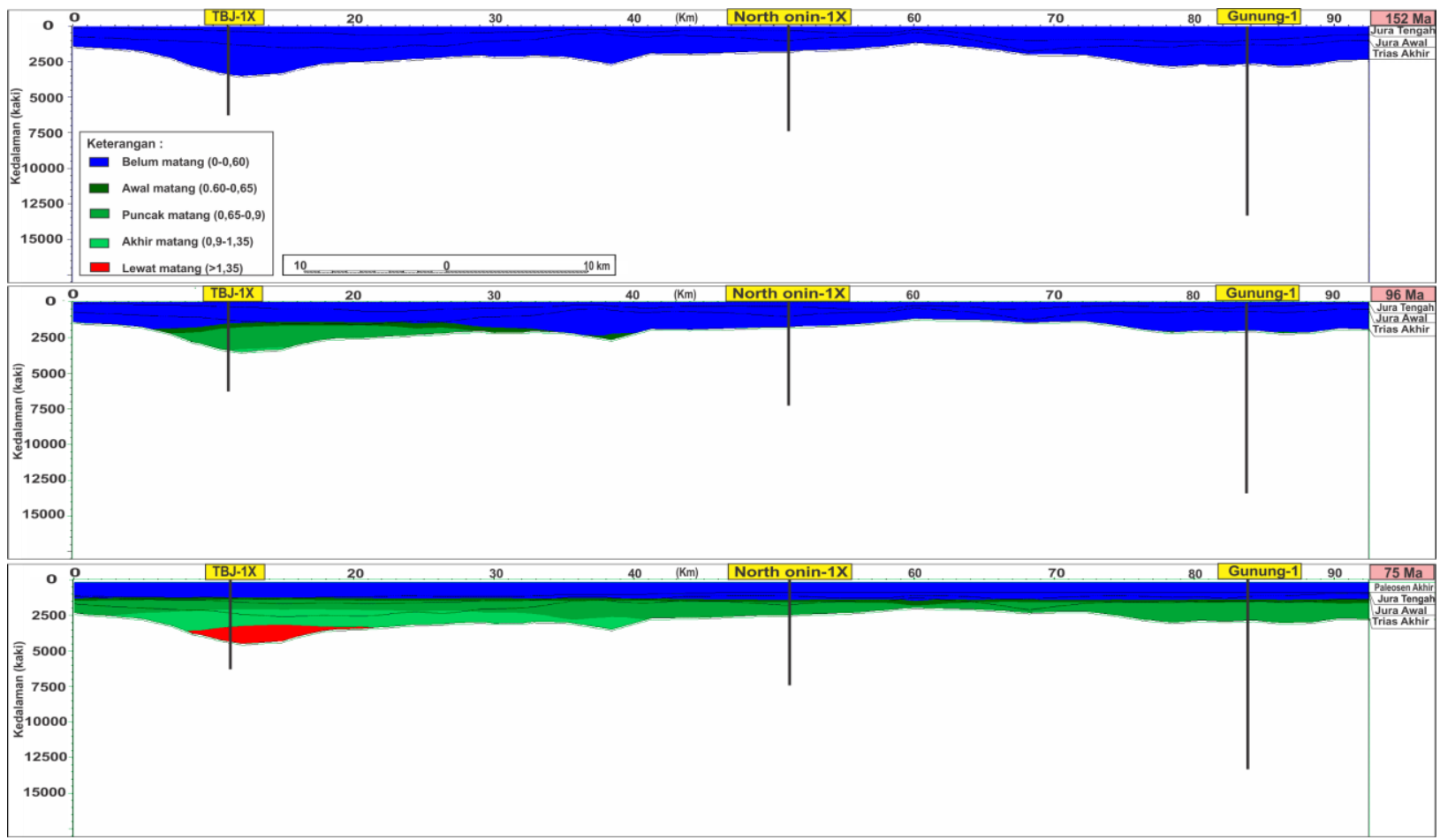

Gambar 14. Sejarah kematangan dan pemendaman 152-75Ma. 


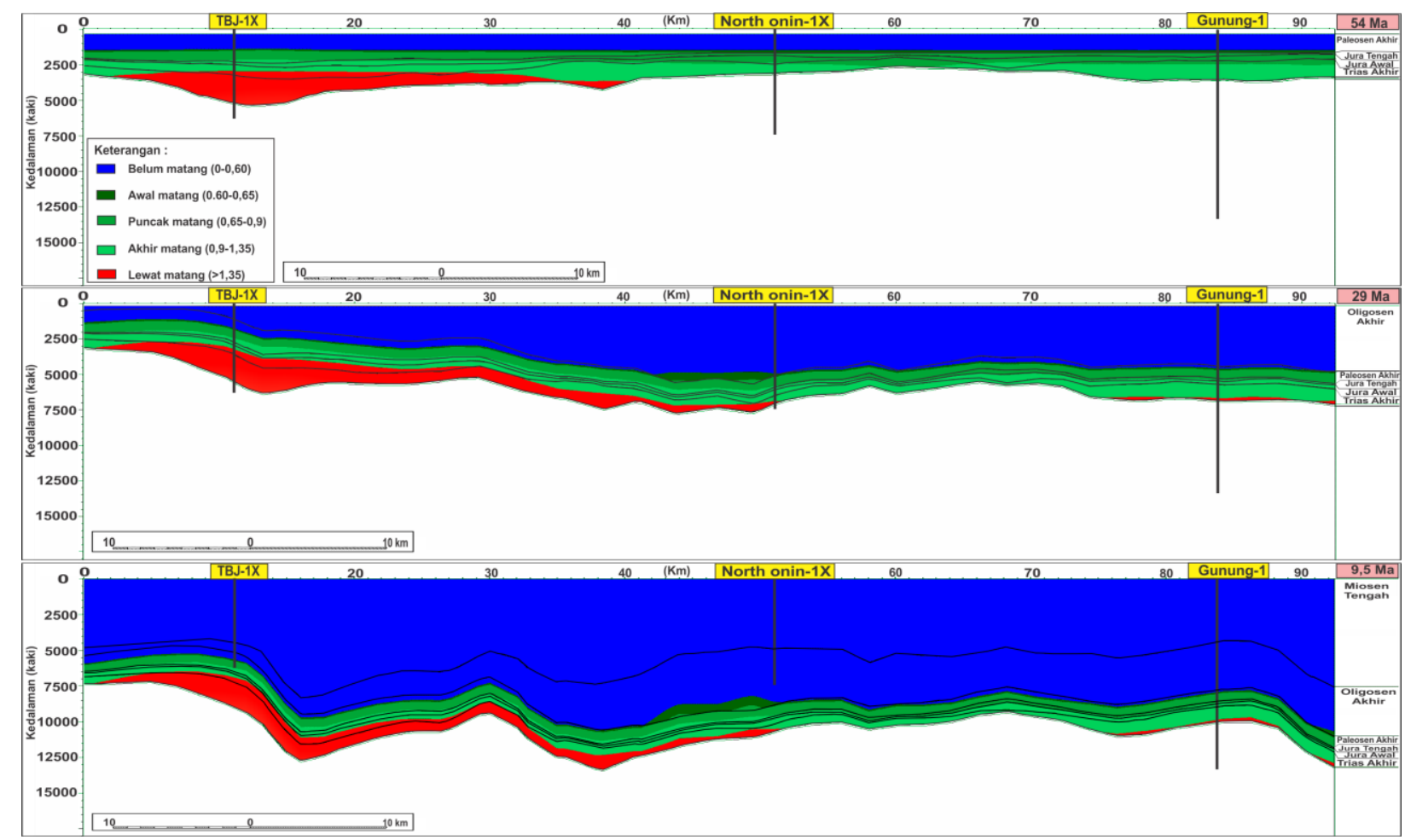

Gambar 15. Sejarah kematangan dan pemendaman 54-9,5 Ma.

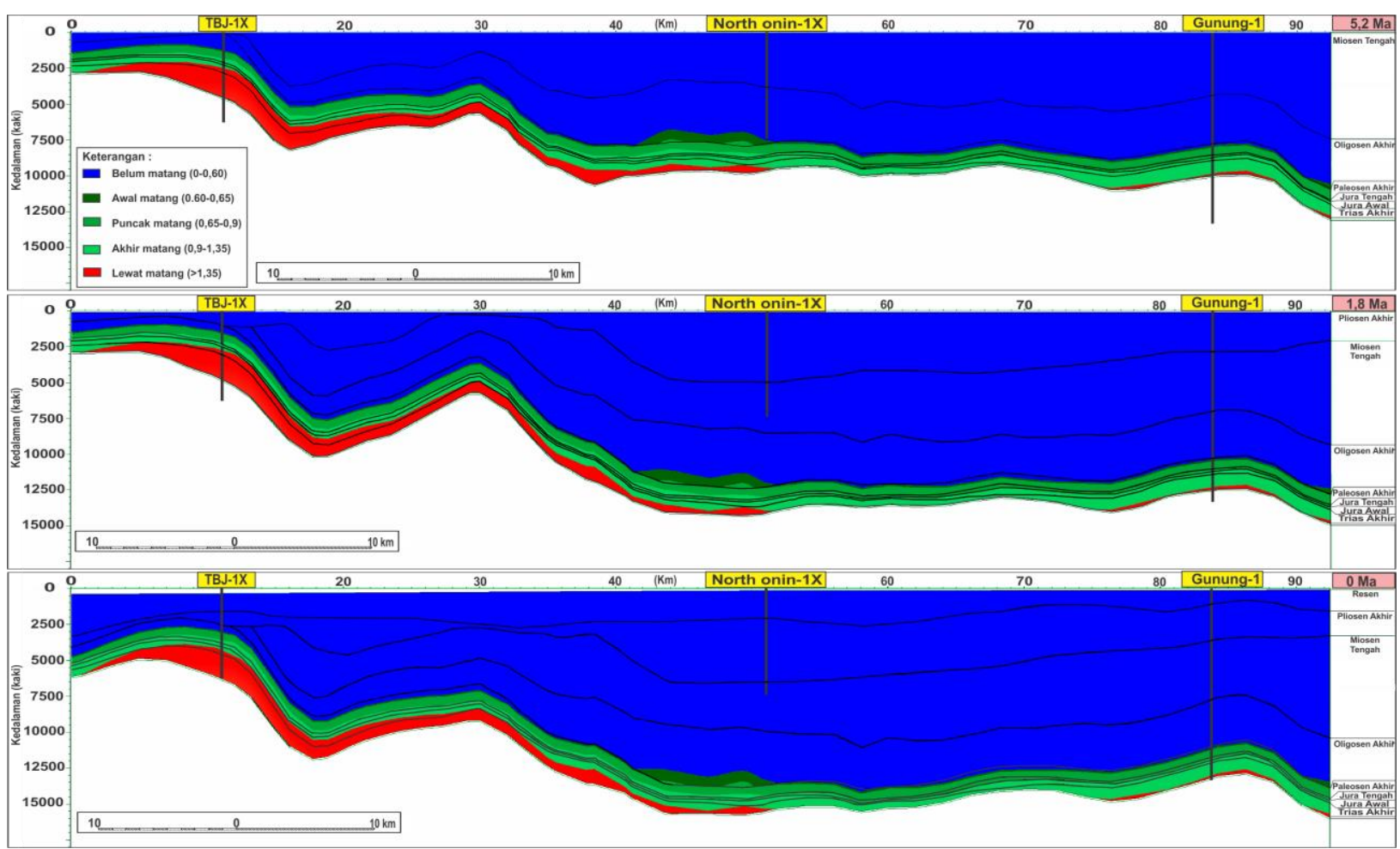

Gambar 16. Sejarah kematangan dan pemendaman 5,2-0 Ma. 


\section{KESIMPULAN}

1. Pada sumur Gunung-1 formasi yang berpotensi menjadi batuan induk adalah Formasi Kembelangan Bawah (Jura Awal) dan Formasi Tipuma (Trias Akhir).

2. Formasi Kembelangan Bawah memiliki TOC berkisar 0,1-13,88 wt\%, tergolong buruk sampai luar biasa, tersusun atas kerogen tipe II dan III, dan menunjukkan kematangan matang puncak sampai matang akhir.

3. Formasi Tipuma memiliki TOC berkisar 0,72-2,49 wt $\%$, tergolong cukup sampai sangat baik, tersusun atas kerogen tipe II dan III, dan menunjukkan kematangan matang akhir.

4. Analisis biomarker menunjukkan bahwa sampel minyak berkorelasi positif dan menandakan minyak tersebut satu famili. Sampel minyak dan sampel batuan Formasi Kembelangan Bawah berkorelasi positif. Keduanya berasal dari sumber yang sama yaitu pada lingkungan pengendapan estuarin tersusun atas material darat dan alga laut. Hal ini menandakan minyak dihasilkan oleh Formasi Kembelangan Bawah.

5. Pada saat ini Formasi Kembelangan Bawah pada sumur Gunung-1 berada pada kematangan matang akhir. Formasi ini memasuki tahap matang awal pada Kapur Akhir, matang puncak pada Paleosen Akhir dan matang akhir pada Eosen Tengah

6. Cekungan Berau telah memiliki elemen sistem petroleum yang lengkap. Selain kelengkapan sistem petroleum itu, waktu pembentukan masing-masing elemen merupakan hal yang sangat penting. Minyak mulai terbentuk pada Kapur Akhir dan puncak pembentukan pada Paleosen Akhir sedangkan perangkap (Antiklin Misool-Onin-Kumawa (MOK) mulai terbentuk pada Pliosen. Minyak yang telah terbentuk tidak akan terakumulasi pada perangkap yang berumur jauh lebih muda. Minyak telah terperangkap pada perangkap-perangkap yang lebih tua. Berdasarkan hasil pemodelan ini, eksplorasi selanjutnya disarankan untuk menggunakan play baru dengan perangkap-perangkap yang terbentuk sebelum minyak terbentuk agar terakumulasi dengan baik. Perangkap Antiklin MOK tetap menjadi target menarik untuk dieksplorasi karena kemungkinan diisi oleh batuan induk yang matang lebih muda dari kematangan batuan induk Cekungan Berau.

\section{DAFTAR PUSTAKA}

Burnham, A.K. (1989): A simple kinetic model of petroleum formation and cracking, Lawrence Livermore National Lab Report, USA. 11.

Kesumajana, A. H. P. (1997): Pengembangan Perangkat Lunak Untuk Pemodelan Komputer Geohistori Cekungan Di Indonesia, Tesis Program Pascasarjana, Institut Teknologi Bandung.

Peters, K.E., dan Cassa, M.R. (1994): Applied source rock geochemistry. The Petroleum System from Source to Trap, AAPG Memoir, 60, 93-117.

Syaifudin, M. (1999) Studi koreksi pemantulan vitrinit pada formasi Brown Shale cekungan Sumatera Tengah, Tesis, Teknik Geologi-FIKTM ITB, 77

Waples, D.W dan Machihara, T. (1991): Biomarkers for geologist- a practical guide to the application of steranes and triterpanes in petroleum geology. $A A P G$ Methods in Exploration series.

$$
\text { 9, 1-65. }
$$

Wygrala, B.P. (1989) Integrated Study of Oil Field in the Southern Po Basin Northen Italy, Ph.D. Dissertation University of Cologne, 217.

Yunus, F. (2010): Geologi Daerah Sorong Kota Sorong Papua Barat, Tugas Akhir Program Sarjana, Institut Teknologi Bandung. 